\title{
ORIGIN OF CITIZENS AND IMPACT ON CITY
}

DOI: 10.18485/arh_pt.2020.7.ch33

\author{
_ Nikola Z. Furundžić \\ Dentist, Dental practice "Furundzic ordinacija" \\ Belgrade, Serbia, stomordinacija227@gmail.com

\section{_ Dijana P. Furundžić} \\ Dentist, Dental practice "Furundzic ordinacija", \\ Belgrade, Serbia, stomordinacija227@gmail.com
}

\author{
_ Aleksandra Krstić-Furundžić \\ Full professor, PhD, Faculty of Architecture, \\ University of Belgrade, Bulevar kralja Aleksandra 73/II, \\ 11000 Belgrade, Serbia, akrstic@arh.bg.ac.rs
}

\begin{abstract}
Cities represent the most populous places. They represent dynamic environments that are subject to constant changes, which in terms of physical manifestation take place in the vertical and horizontal directions. This is especially related to the desire to live in cities, which has dominated the population throughout the history of civilization. The development of cities is generally proportional to the flow of new residents looking for a place to live in a city. The process of urban growth in both vertical and horizontal directions is considered to be accompanied by a constant increase in urban population. This trend that cities will have in the future is indicated by worldwide predictions. Population growth in cities can happen in two ways, the first being natural growth and the second is migration of people. Migration can be further classified and therefore split into two groups: internal rural-to-urban migration and international urban migration. The immigrants bring with them different cultural characteristics (clothing, customs and behavior), habits and beliefs in the cities in which they will continue to live and strive to maintain them. Also, the characteristics of their architectural heritage tend to incorporate in these areas. Migrations can lead to anthropological modifications, introduce new cultural rules, and change the shape of the city with the introduction of new patterns of cultural and building heritage. However, migrants need to adapt to new conditions and rules of life and business, changing the way of daily activities and diet, which can lead to psychological and health problems. This paper aims to discuss, systematize and review some of these influences and processes and to view them in the context of responsible behavior in an urban environment.
\end{abstract}

KEYWORDS _ population growth, migration of people, responsible behaviour

\section{INTRODUCTION}

The desire to live in cities dominates over the population in the entire history of civilization, especially in recent times in the last century. Cities represent the most populous places for living on the planet. They represent dynamic environments that undergo constant changes, including changes in physical characteristics. The process of urban growth in spatial terms takes place in a vertical and horizontal direction and is mainly the result of a permanent increase in the urban population. This 
is a trend that cities will have in the future, as indicated by worldwide predictions. According to the United Nations Population Fund, 2008 marked the year when more than 50 percent of all people, 3.3 billion, lived in urban areas, a figure expected to rise to 70 percent by 2050 (UN, 2008). In Europe, 75 percent of the population already lives in urban areas and the number is expected to reach 80 percent by 2020 . This continuous trend of urbanization, one that has been consistent since the 1950s, means an additional 2.5 billion people (more than a third of our current global population) will be living in cities by 2050 (UN, 2014). The Graph 1 illustrates this global trend.

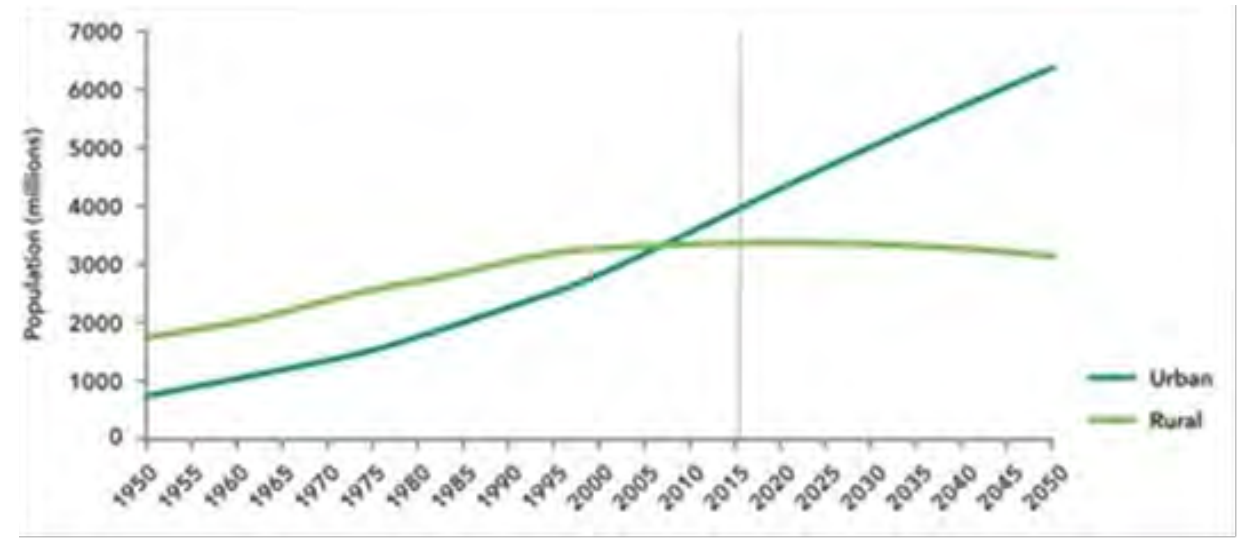

_ Graph 1: Urban and rural population of the world, 1950-2050 (UN, 2014, pp. 7)

Urban population growth can happen in two ways, the first being natural growth and the second is a migration of people involving different processes, as presented in Figure 1. Migrations can be further classified depending on the type of process represented and therefore divided into two groups based on the origin of the migrants. If occurring in the territory of one state it is called internal migration, mostly rural-to-urban migration. The movement from one country to another is called international urban migration.

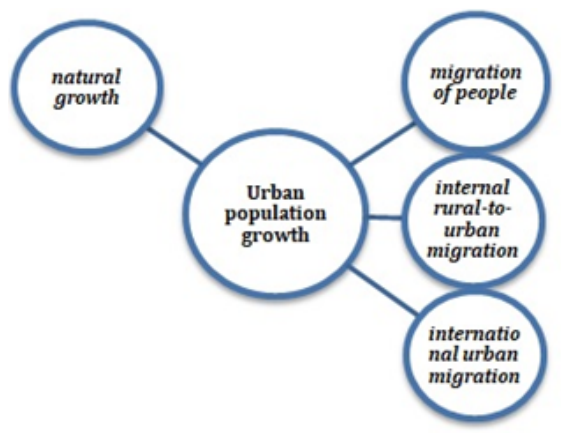

_ Figure 1: The ways/processes of urban population growth

„Migration of people, both legal and illegal, will account for more than two thirds of urban growth in high-income countries. Without immigration, the urban population in these countries would probably decline or remain the same in the coming decades" (WHO, 2010, pp. 5). Migrants opt for countries with a high standard of living and cities that have a large population. Over $50 \%$ of the population of Dubai and Brussels is foreign-born due to their highly mobile workforces (Kerr, 2019, pp. 107; WEF, 2017 , pp. 26). It is estimated that roughly 20 countries attract more than two-thirds of all potential migrants worldwide (Esipova et al., 2017). Migrants from other parts of the country or around the 
world have contributed to the growth and development of most cities, and now they are part of the history and fabric of the city, and all residents should be aware of this and should acknowledge their existence. Sociologist Saskia Sassen points out that the role that cities have historically taken in empowering migrants should also be taken seriously (Stott, 2016). Migrants are attracted by the possibilities that cities can offer. The direction of movement of people from rural areas to urban areas has shown the same direction for centuries that are likely to persist in the future, also contributing to the rapid expansion of cities. Migration as a continuous process is expected only to increase, from an estimated 244 million international migrants in 2015 , while internal migration is three times that of international migration (763 million according to the latest official estimates), affecting the lives of far more people, although it is given much less attention in political debates and planning processes (WEF, 2017, pp. 10).

In urban population growth mostly all the above mentioned processes are represented, but usually do not have an equal impact. There are many factors that affect the process of urban growth, and determine which of these processes will dominate. This indicates that people living in cities are of different origin and genetic diversity, and variations depend on the dominance of the aforementioned processes. The diversity is more pronounced when it comes to international migration. The composition of the population structure living in urban areas is based not only on origin but also on financial status, level of education, employment-unemployment status, etc.

Migrants have different cultural backgrounds that they want to integrate into the places they have immigrated to, and some impacts of this process are discussed from an architectural point of view in this paper. However, migrants need to adapt to new conditions and rules of life and business, changing the way of daily activities and diet, which can lead to psychological and health problems. By associating and exchanging genetic material between the society of natives and newcomers, both societies transmit anthropological characteristics. This paper aims to discuss, systematize and review some of these impacts and processes and to view them in the context of responsible behavior in an urban environment. The methodological approach includes original analyses of scientific publications that consider this issue and the selection and analysis of selected case studies.

\section{CONSIDERATIONS FROM THE ARCHITECTURAL POINT}

The immigrants possess and bring a variety of cultural characteristics (clothing, customs and behavior), habits and beliefs to the cities in which they will continue to live and tend to incorporate them in different ways, in order to preserve them. Also, the properties of their architectural heritage they would like to be integrated into these areas. Migrations can lead to anthropological modifications, introduce new cultural rules, and change the shape of the city with the introduction of new patterns of cultural and building heritage.

The impact of migration on urbanism and architecture is recognized by many researchers, architects and practitioners as a real situation and as a major challenge. Considering the introductory lectures at the reSITE conference "Cities in Migration" held in Prague in 2016, in his article entitled Migration Will Define the Future of Urbanism and Architecture, Rory Stott (2016) noted that migration is a topic that architects must understand and respond to. At that conference sociologist Saskia Sassen pointed to three types of migrants: the political refugee, those fleeing political turmoil in their homes, the economic migrant, who seeks a better life in a new country, and the "economic refugee," a class of people who are fleeing the "massive loss of habitat" catalysed by economic activities such as corporate land-grabs and mining, or by encroaching environmental disasters, while critic Michael Kimmelman added migrants fleeing environmental disasters and made the threat of climate-driven migration (Stott, 2016). At the end of this article, Stott concludes: „With such a range of different causes of migration, one thing that was clear from the conference's opening was that at the level of cities, the key question of migration is how diversity is acknowledged, respected and accommodated by the built environment."

The fact is that many large cities, which migrants mostly gravitate to, are characterized by high 
housing prices, which is one of the key problems for immigrants and their integration and survival. For this reason, as well as the lack of cheap affordable housing, a large number of immigrants live in slums and informal settlements. The absolute number of slum dwellers continues to increase. (UN HABITAT, 2016, pp. 57). All this speaks in favor of the undeniable importance of reconsidering the options of reusing vacant buildings, as existing physical structures in the city, redeveloping built-up areas within the city, and using empty, often abandoned urban spaces to build safe and affordable housing for migrants.

Using the existing building stock can provide the asylum seekers and refugees with a proper shelter in one hand and also can contribute to revitalization of decaying locations with the newcomers' participation, on the other hand which consequently enhances socio-spatial sustainability (Razavivand Fard and Mehan, 2018). Two examples of temporarily housed refugees in abandoned buildings in Berlin and Turin are worth mentioning. The first is Germany's largest refugee shelter inside Berlin's Tempelhof Airport (Figure 2, left) and the second is occupying abandoned Olympic Village by refugees in Turin (Figure 2, right), now called Ex-Moi, discussed by Razavivand Fard and Mehan (2018). More than a million refugees from Syria are estimated to have arrived in Germany by the end of 2015 in hopes of a better life (Lupieri, UNESCO MGIEP). Some 85 percent of asylum seekers in Berlin are housed in mass shelters and only 15 percent in private flats (Conrad, 2016). Since 2015, Tempelhof Airport has become Germany's largest temporary refugee shelter for refugees from countries like Iraq and Syria (Shead, 2017). The disadvantage turned out to be that refugees live in cubicle-type structures with little privacy.
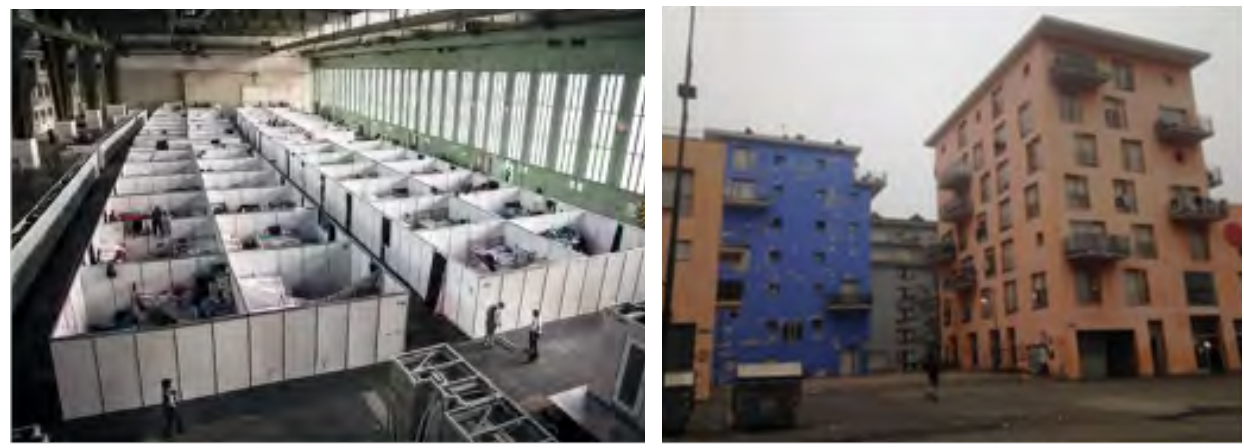

_ Figure 2: Refugee shelters inside Berlin's Tempelhof Airport (left, @Gordon Welters for the New York Times) and Olympic Village in Turin, Italy (right, Photograph: Claire Provost)

Olympic Village in Turin, Italy, abandoned after the Games for almost 7 years till it got occupied in 2013 by the North African refugees (Belloni and Pallotta, 2016) from almost 30 different ethnic groups. This case well manifests the social and spatial segregation of these squatting people where they live in a modern ghetto-like settlement, surrounded by the railways (Razavivand Fard and Mehan, 2018). The debates about this informal settlement are still ongoing; some political parties are opposing and many social activists are on the refugees' side to compensate the insufficiency of the local supporting polices.

The importance of building experimental housing and settlements or camps for affordable housing is undeniable, both because of the accommodation of immigrants and because of gaining experience based on the lessons learned. During the reSITE 2016 Conference, Carl Weisbrod, director of NYC's City Planning Commission, discussed the city's commitment to low-income housing by presenting New York City's experiment with micro-apartments on Carmel Place, conceived as a way of providing cheap, single-occupancy apartments in the very center of a city that has an overabundance of homes designed for families or the super-rich, indicating a commitment to preserving and encouraging diversity (Stott, 2016). According to Eric Bunge, a member of the nArchitects team, the aim was to provide a new social framework for small households that emphasizes nested scales 
of community rather than individual residents (Bernard, 2018). Forty percent (22 unites) of the 55 rental units in Carmel Place are dedicated to affordable housing (http://narchitects.com/work/carmel-place/). By incorporating setbacks in the design of the stepping "micro-towers", Carmel Place's urban form could in principle be adapted to different sites, at a range of heights and floor area ratios, and at nearly any location in a block (World-Architects, 2016). In the publication Carmel Place Innovative Practices for Healthier Homes (2019), it is explained that the construction of Carmel Place (Figure 3) consisted of fabrication, transportation and stacking of 65 individual steel framed modules, ready for installation of appliances and interior finishes, which enabled the reduction in on-site construction, and also brought some reduction in the cost of the building itself. The same publication points to implemented innovations such as reduced apartment size, with the addition of a variety of communal spaces to support living in a small space, and a focus on health in terms of light and air by installing high ceilings with large operable windows.
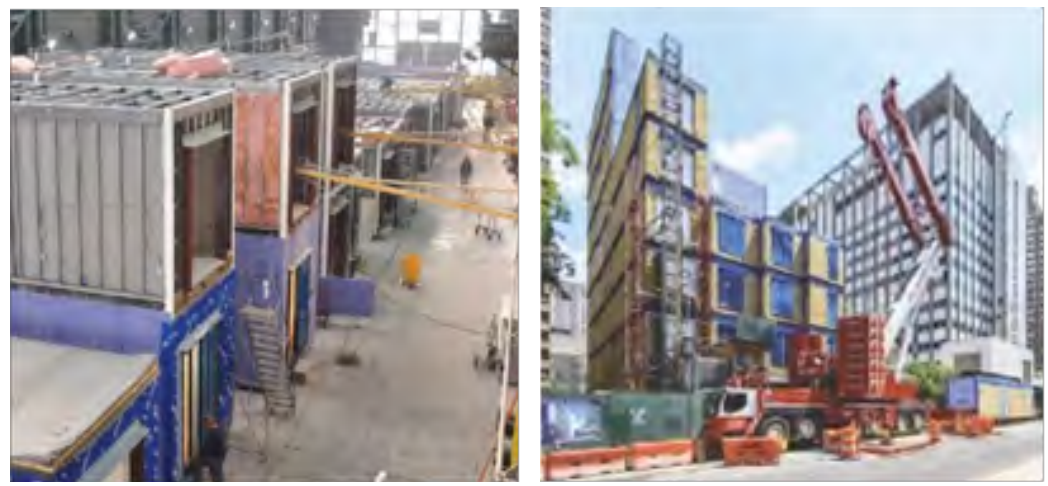

_ Figure 3: Fabrication and stacking of the steel framed modules of the Carmel Place building. (Source: Carmel Place Innovative Practices for Healthier Homes, A Case Study, 2019)

Carmel Place building is an example of a massive, solid building that has the character of a longterm structure located in the urban fabric, a type that for a wider application requires a rethinking of the existing approaches from political, social, urban design, legislative, health and other aspects related to migration. Cities are under pressure to build affordable and social housing that is financially viable, complies with design and safety standards, and can be delivered in a short amount of time; the option is to explore avenues to repurpose vacant space, apartments or underutilized buildings in the city for temporary or long-term housing of migrants.

When it comes to affordable housing and accommodation of migrants, Joana Dabaj, a participant in the reSITE 2016 conference, said: "When dealing with the crisis and urgent situations there's also this requisite that you need temporary structures ... it can be disassembled and assembled" (Stott, 2016). Refugee shelters are structures ranging from the most temporary tent accommodation through the transitional shelter to building temporary pics and settlements and include the most basic kind of ad hoc structure (https://en.wikipedia.org/wiki/Refugee_shelter). A unique collaboration between the IKEA Foundation and the UNHCR has resulted in a new, innovative, safer and more durable shelter for refugee families around the world named the Better Shelter (Figure 4, left), which is a flat-pack temporary shelter designed with special attention to transport volume, weight, price, safety as well as health and comfort, and can be assembled on site without additional tools and equipment, and is fitted with a solar panel (IKEA Foundation, 2015). A solar panel installed on the roof adds precious value to the little house by allowing it to generate its own electricity and charge a LED light for up to four hours (Garofalo, 2016). The expected lifespan of this temporary shelter is three years, which is a very short-term. 

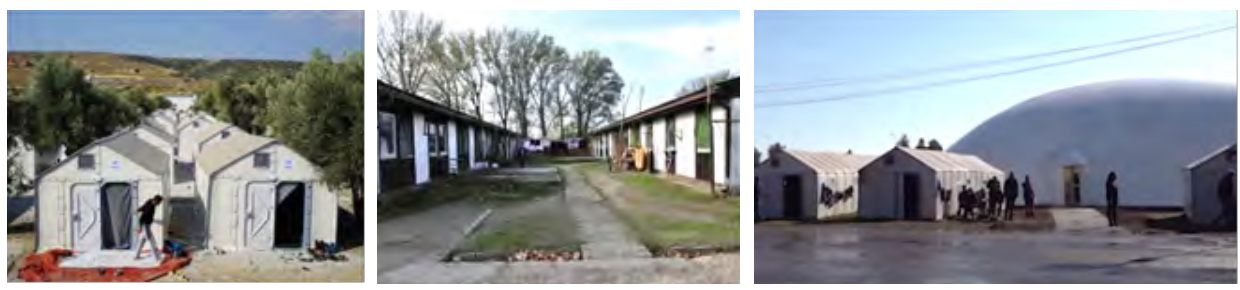

- Figure 4: Better Shelter in the Karatepe transit camp in Mytilini on the island of Lesbos, Greece (left, Source: Greece @ Better Shelter, Frederica Garofalo, 2016), refugee camp in Krnjača (middle, Source: https://www.lobi-info.rs/zatvara-se-izbeglicki-kamp-u-krnjaci/) and Obrenovac reception center, (right, Source: http://www.rtvmag.co.rs/24_sata_o_obrenovcu_objava.php?o=10521), Serbia

A survey conducted by Lažetić and Jovanović (2018, pp. 14) shows that after the closure of the Balkan Route, most of the migrants and refugees who remain "stuck" in Serbia are of lower economic status, mostly single men from Afghanistan, Pakistan, Algeria, Morocco, Somalia, Syria, and Tunisia, while arrivals in September 2017 show a demographic shift to families from Afghanistan, Iraq, and Syria (Praxis, 2017). They note that migrants who can afford to rent their own rooms and apartments often live in hostels or apartments around the main train and bus station. Informal conversations with migrants and refugees showed that they still do not see their future in Serbia (Lažetić and Jovanović, 2018, pp. 18). Local communities are supported to build or renew shelter space for refugees. One such renovation is the old military quarter in Obrenovac which is now turned into a reception center hosting migrants who previously lived in informal settlements in Belgrade's city center. In 2020, the capacities for accommodating migrants were expanded with the construction of light prefabricated facilities (Figure 4, right). In Krnjača, in a settlement originally made for workers of the Ivan Milutinovic Company (PIM), two barracks were allocated to accommodate migrants. The barracks were built as temporary buildings, of wooden prefabricated construction (Figure 4, middle). Migration was the central theme of the 2019 Venice Art Biennale in Venice. From the standpoint of this paper, the following comment is interesting: " 'We, Elsewhere' juxtaposes the memories people have of where they come from with the memories people made when they went elsewhere", and Inci Eviner introduced the need and hopes to "evoke the sense of a search for the missing, the erased, and that which is 'elsewhere" (Sanderson, 2019).

In cities, immigrants are more likely to integrate by joining large numbers of fellow immigrants in communities where they find a familiar language and support networks (McKinsey Global Institute, 2016, pp. 3). Migrants especially need to be gathered in big cities. For example, of the 6.8 million foreign-born people living in Canada, $46 \%$ reside in Toronto (IOM, 2015, pp.38). The high proportion of migrants in cities enhances their global character in terms of culture and social customs (WEF, 2017, pp. 26). In many large cities, there are districts inhabited by foreign-born people, which gives them a sense of belonging, facilitates communication in their mother tongue, maintaining customs and habits of nutrition, such as Italian, Turkish, Chinese, Arabic and other neighborhoods. Some of these neighborhoods in European cities have a long history, while others are still a relatively new development. Such areas are recognized by certain typical architectural features, shops, restaurants, bakeries, pastry shops, etc. (Figure 5). Migrants need to go to their temples and want them to have the architectural characteristics of the original ones, which is usually available in the case of neighborhoods with many migrants of the same religious affiliation, but this is generally not easily achievable. Buildings for some other purposes can, due to their shape characteristics, sometimes resemble such objects and thus create a visual illusion and a sense of pleasure and calm. It is noticeable that the original types of decorations, language symbols, elements of equipment and furniture give a visual character and colors to the streets of such neighborhoods. 

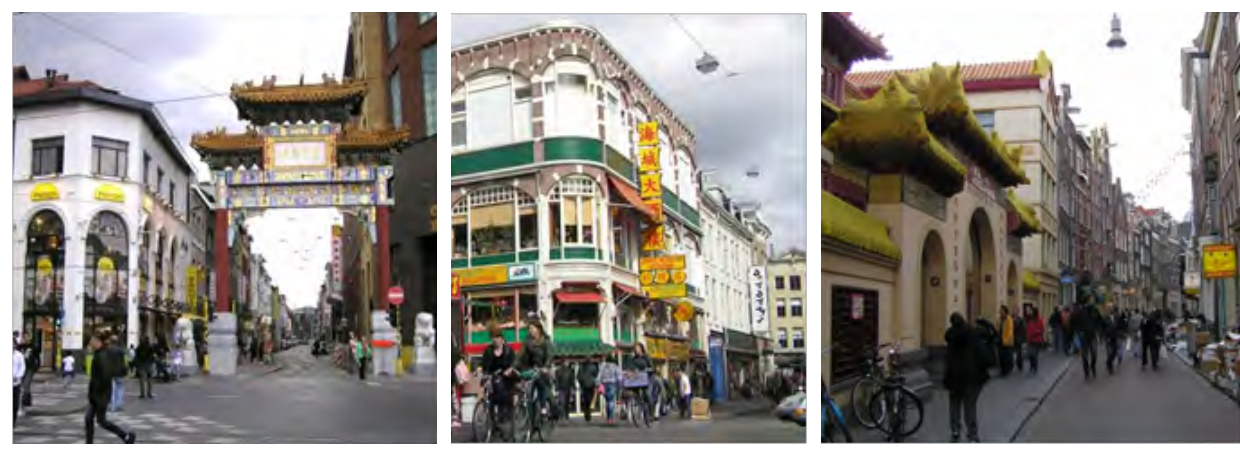

_ Figure 5: Certain typical architectural features, shops, and restaurants represent different cultural milieus of migrants (left-Antwerpen, middle-Amsterdam and right-Cambridge).

\section{CONSIDERATIONS FROM THE MEDICAL POINT}

We are aware of the fact that migrants need to adapt to new conditions and rules of life and business. This may require a change in the previous usual, original way of daily activities and diet, which can lead to psychological and health problems.

Large slums of over one million residents can be found in many of the world's megacities. Around a quarter of the world's urban population lives in slums due to poverty in conditions that can lead to poor health resulting from overcrowdedness and a lack of potable water and proper sanitation (WEF, 2017, pp. 32).

Urban population is composite form of society and it is compound from origin people, internal immigrants and international immigrants. Also for immigrants it is important how long they are present in that urban area. So it can be from 0-5 years, or 5 to 10 years or more than 10 years or short, medium or long term stay in that city. It is important to know the age of the settlers, so that the possibility of their adaptation to the new environment of the city or urban area can be foreseen. Also, this information is important for building an appropriate way of communication and is important for the service industry such as medicine, police, social services and job creation. The effect of the adaptation process on mental health in particular depends on e.g. social network, gender, age, language skills, educational level, religious beliefs, the reasons for migration and the reception upon arrival in the recipient country (Kristiansen, Mygind, and Krasnik, 2007). The conditions in which migrants were born, lived and worked originally affected their health. Furthermore, health was affected by conditions during their migration. Mental and physical health are equally important for the process of adapting to new conditions. Migrants living in slums have unfavorable living conditions, which leads to worsening physical, mental and social risks. Staying in refugee camps is also an existentially insecure option and can have a negative impact on the well-being of migrants. These situations can cause high levels of anxiety, resulting in, for instance, higher blood pressure, or can manifest indirectly through unsafe practices (drug abuse), inadequate resources to prioritize the prevention of diseases or to seek access to healthcare when required, or poorer adherence to medical counsel (WEF, 2017, pp. 33). The problem of being able to adapt mainly extends through the first and second generations of migrants.

Migrations involve the relocation of the population from one territory to another. Moving from one area to another and staying in it, migrant groups leave their mark on a certain territory. Not only are the customs exchanged and adopted between the society of natives and newcomers, but by associating and exchanging genetic material, both societies also transmit anthropological characteristics. With the development of humane, i.e. medical genetics, it has become possible to understand the essence of the biochemical basis of heredity. Thanks to Mendel's research, the basic unit for the transmission of traits, the Gene, and the ways of their exchange that contribute to the development 
of various traits, was established (Marković and Trišović, 1986, pp. 98, 99). In this paper, given the professional orientation of some authors of this article, attention will be focused on dentofacial complex, especially jaw orthopedics.

From the aspect of jaw orthopedics, genetic characteristics are important for monitoring the occurrence of irregularities of the jaw complex, as well as their appearance through the generations. The presence of irregularities of the dental arches and the entire dentofacial complex affects the development of generations and their proper functioning, which is one of the important conditions for the formation of a healthy society.

Thanks to the mixing of genes from different populations, conditions are obtained for the interpretation of certain phenomena, in the sense of whether they should be viewed as an irregularity or a normal characteristic of a climate. In the classification of jaw irregularities, there is the term Bimaxillary protrusion, which describes the specific appearance of the face and jaw, followed by the protrusion of the front upper and lower teeth in combination with full and protruding lips. While bimaxillary protrusion is considered an irregularity in members of the white era, in members of the black race it is an ethnic characteristic, which fits the specific architecture of the skeletal skull and face. (Marković et al., 1986, p. 221).

The assessment of jaw irregularities is done by appropriate analyzes of study gypsum models and $\mathrm{X}$-rays. This is an analysis of the space of the dental arches, which is of an international character and is necessary in the proper diagnosis and planning of therapy for malocclusions. A.M. Schwartz based his analysis on a study of the mixed Viennese population (Tanić et al., 2002, p. 60). Thanks to the reference values that were formed on the population of a certain type of mixing, this analysis is today widely used in orthodontic diagnostics in a number of ethnic groups. In addition to Schwartz, there is also Pont's analysis whose reference values are based on studies of the population of Southern France, while Hart's analysis corresponds to the population of Northern Germany (Lapter and Ozerović, 1986, p. 171), and as such, they are usable mainly in these climates.

Based on this, it can be concluded that there are difficulties in determining standard values for evaluating whether something should be viewed as an irregularity or anthropological characteristic, and that mixing of different populations requires finding new parameters that could standardize the dentofacial condition and declare it normal for a number of ethnic groups.

There are numerous epidemiological studies that show the prevalence of health problems and cover various branches of medicine and dentistry. Given that this work examines human migration, it is necessary to point out that such changes in society are highly influential and that it is difficult to define them as positive or negative. Migrations are so specific that the positive influences of newcomers can be easily diminished by some of their negative characteristics. It is difficult to say whether migration has the same impact in all climates given that some populations in their habitat are more tolerant of changes than others.

\section{CONCLUSIONS}

Cities are definitely popular human habitats and as such are constantly exposed to change. Society is a component of the city that initiates the greatest number of changes, wanting to create the most comfortable living conditions for itself. In addition to migrations, people are exposed to frequent travel, and now it is easy to get to the most remote areas. These are all conditions in which the transfer of the influence of one society to another is enabled. These influences should be mutual. The exchanges of experiences and customs in various industries contribute to the end product being of better quality, but also cheaper.

In this paper, through the conducted considerations, it was noticed that immigrants bring with them different cultural characteristics, habits and beliefs and try to keep them in the cities where they will continue to live. It has been shown that they tend to incorporate the characteristics of their architectural heritage into these areas. This needs to be taken into account when considering suitable forms of affordable housing, which is a remarkable challenge, as pointed out in this paper. 
The mixing of cultural customs and genetic material among individuals can produce a considerable number of positive changes and the emergence of new trends. Thus we get that certain irregularities of the orofacial region are interpreted as desirable traits, and certain customs lead to a balance in the behaviour, especially of the young.

Migration is extremely present nowadays, and the fact is that the issues of adaptation and integration of migrants into the new environment, as well as the issue of coexistence of different cultures, represent current challenges for various professions involved in urban development and well-being of inhabitants, and some of these challenges are highlighted in this article.

\section{REFERENCES}

- Belloni, G. and Pallotta, G.S. 2016. Grassroots Culture as the Key for the Revitalization of urban Peripheries: The Case of Refugees Squat in Turin's Former Olympic Village. Turin, Italy: Track 2_Imageries of cities: The role of cultural policies and activisms in self-representation of cities and citizens.

- Bernard, Murrye. 2018. When Less Space Invites More Regulations. Architect, the Journal of the American Institute of Architects, February 22, 2018. Accessed January 3, 2020. https://www.architectmagazine.com/practice/when-less-space-invites-more-regulations_o

- Carmel Place Innovative Practices for Healthier Homes, A Case Study. 2019. Parsons Healthy Materials Lab. Accessed December 27, 2019. https://healthy-materials-lab.s3.amazonaws.com/news/Carmel-Place_Proof-compressed.pdf

_ Conrad, Naomi. 2016. "Berlin activists condemn mass refugee shelters." Deutsche Welle, Berlin

_ Esipova, Neli, Julie Ray, and Anita Pugliese. 2017. "Number of Potential Migrants Worldwide Tops 700 Million". Gallup News, 8 June 2017. Accessed December 27, 2019. http://www.gallup.com/poll/21 1883/ number-potential-migrants-worldwide-tops-700-million.aspx.

- Garofalo, Federica. 2016. IKEA and UNHCR come together to build a Better Shelter for refugees. Lifegate. Accessed February 3, 2020. https://www.lifegate.com/businesses/news/ikea-unhcr-better-shelter

_ https://en.wikipedia.org/wiki/Refugee_shelter Accessed March 15, 2020.

_ http://narchitects.com/work/carmel-place/ Accessed March 15, 2020.

_ http://www.rtvmag.co.rs/24_sata_o_obrenovcu_objava.php?o=10521 Accessed March 5, 2020.

- IKEA Foundation. 2015. Better Shelter, IKEA Foundation and UNHCR ready to improve life for thousands of refugee families. Accessed March 15, 2020. https://ikeafoundation.org/press-release/better-shelter-ikea-foundation-and-unhcr-ready-to-improve-life-for-thousands-of-refugee-families/

_ IOM. 2015. World Migration Report 2015 - Migrants and Cities: New Partnerships to Manage Mobility. International Organization for Migration (IOM).

- Kerr, Juliana. 2019. "Migrants need Cities, Cities Need Migrants." In The Century of Global Cities, How Urbanisation Is Changing the World and Shaping our Future, edited by Andrea Tobia Zevi, Milano: ISPI.

- Kristiansen, Maria, Anna Mygind Research and Allan Krasnik. 2007. Health effects of migration. Danish Medical Bulletin, 54(1):46-47.

_ Lapter, Vladimir and Borka Ozerović. 1986. "Metode dijagnostike malookluzije." In Ortodoncija, edited by Milan Marković, 160-196. Beograd: Ortodontska sekcija Srbije.

_ Lažetić, Marina and Teodora Jovanović. 2018. Belgrade, Serbia / A Case Study of Refugees in Towns. Tufts University.

- Lupieri, Sigrid. From refugee camps to German classrooms: Syrian students build a new life in Germany. UNESCO MGIEP. Accessed March 15, 2020. https://mgiep.unesco.org/article/from-refugee-campsto-german-classrooms-syrian-students-build-a-new-life-in-germany\#

_ Marković, Milan and Dimitrije Trišović. 1986. "Etiologija malookluzija." In Ortodoncija, edited by Milan Marković, 97-159. Beograd: Ortodontska sekcija Srbije.

- Marković, Milan, Simka Serafimova, Živojin Vidović and Bećir Ljupči. 1986. "Malookluzije." In Ortodon- 
cija, edited by Milan Marković, 197-239. Beograd: Ortodontska sekcija Srbije.

- McKinsey Global Institute. 2016. People on the move: Global migration's impact and opportunities Executive Summary.

_ Praxis. (2017). Praxis Protection Monitoring Report on Migration - September 2017. [online] Accessed March 15, 2020

_ http://praxis.org.rs/images/praxis_downloads/Praxis_Protection_Monitoring_Report_September_2017.pdf

- Razavivand Fard, Haniye and Asma Mehan. 2018. "Adaptive reuse of abandoned buildings for refugees: lessons from European context." In Suspended Living in Temporary Space: Emergencies in the Mediterranean Region, edited by Marco Vaudetti, Valeria Minucciani, Simona Canepa, Nilufer Saglar Onay, 188-197. LetteraVentidue Edizioni.

- Sanderson, Sertan. 2019. Sunken migrant vessel displayed at Venice Biennale. Info Migrants. Accessed February 18, 2020. https://www.infomigrants.net/en/post/16869/sunken-migrant-vessel-displayed-at-venice-biennale

_ Shead, Sam. 2017. The story of Berlin's WWII Tempelhof Airport which is now Germany's largest refugee shelter. Independent Journal Review. Accessed February 18, 2020. www.independent.co.uk/news/ world/world-history/the-story-of-berlins-wwii-tempelhof-airport-which-is-now-germanys-largest-refugee-shelter-a7799296.html

_ Stott Rory. 2016. Migration Will Define the Future of Urbanism and Architecture. Accessed February 18, 2020. https://www.archdaily.com/790818/how-migration-will-define-the-future-of-urbanism-and-architecture

- Tanić, Tatjana, Jasmina Milić, and Julija Radojičić. 2002. Uvod u osnovne principe dijagnostike i terapije u ortopediji vilica. Pančevo: Stomatološki fakultet Pančevo.

_ UN. 2008. World Urbanization Prospects: The 2007 Revision Population Database. New York: United Nations Publication.

_ UN. 2014. World Urbanisation Prospects, The 2014 Revision Highlights, 2014, United Nations, New York, Accessed December 18, 2019.

_ https://issuu.com/unpublications/docs/world_urbanization_prospects_2014_h/8

_ UN-HABITAT, 2016. Urbanization and Development: Emerging Futures: World Cities Report 2016. Accessed February 18, 2020. https://unhabitat.org/sites/default/files/download-manager-files/WCR2016-WEB.pdf

- WEF. 2017. Migration and Its Impact on Cities. World Economic Forum (WEF). Accessed January 28, 2020. http://www3.weforum.org/docs/Migration_Impact_Cities_report_2017_HR.pdf

_ WHO, 2010. Hidden Cities: unmasking and overcoming health inequities in urban settings. Chapter 1. The rise of modern cities. World Health Organization.

- World-Architects, 2016. Carmel Place. Accessed December 27, 2019. https://www.world-architects. com/en/architecture-news/reviews/carmel-place-1 